\title{
KETERKAITAN DENSITAS GIZI, HARGA PANGAN, DAN STATUS GIZI PADA ANAK SEKOLAH DASAR NEGERI PEKAYON 16 PAGI
}

\section{(Association between nutrient density, food price, and nutritional status among Pekayon 16 Pagi elementary school children)}

\author{
Annisa Yuri Ekaningrum ${ }^{1 *}$, Dadang Sukandar ${ }^{2}$, Drajat Martianto ${ }^{2}$ \\ ${ }^{1}$ Sekolah Tinggi Ilmu Kesehatan Indonesia Maju, Jakarta Selatan 12610 \\ ${ }^{2}$ Departemen Gizi Masyarakat, Fakultas Ekologi Manusia (FEMA), Institut Pertanian Bogor, Bogor 16680
}

\begin{abstract}
The purpose of this study was to analyze the relationship between energy density and food price, the relationship between nutrient density and food price, and the relationship between nutrient intake density and nutritional status using Body Mass Index for Age (BMI/A). Study design was cross-sectional and subjects were selected using stratified random sampling with proportional allocation. Population were $3 \mathrm{rd}$, 4th, and 5th grade students atPekayon 16 Pagi Elementary School with the total subjects 158 students. Nutrient density was measured by NRF (Nutrient Rich Food) 9.3 index method. The study found that most of the subjects had adequate protein and energy intake density but low calcium, vitamin $A$, and vitamin $C$ intake density. Energy, vitamin A, vitamin $C$, calcium, iron intake density were not correlated with BMI/A ( $p>0.05)$. Energy density was negatively correlated with food price $(r=-0.622)$. Nevertheless, nutrient density was positively correlated with food price $(r=0.614)$.
\end{abstract}

Keywords: BMI-for-age, diet quality, energy density, food price

\begin{abstract}
ABSTRAK
Tujuan penelitian ini adalah menganalisis hubungan antara densitas energi dan harga pangan, hubungan densitas gizi dengan harga pangan, dan hubungan antara densitas asupan zat gizi dengan status gizi menggunakan Indeks Massa Tubuh menurut Umur (IMT/U). Desain penelitian adalah cross-sectional dan subjek dipilih menggunakan metode penarikan sampel acak stratifikasi dengan alokasi proporsional. Populasi adalah siswa/i kelas 3, 4, dan 5 di SD Pekayon 16 Pagi dengan total subjek 158 siswa. Densitas zat gizi pangan diukur menggunakan metode indeks NRF (Nutrient Rich Food) 9.3. Studi ini menemukan bahwa umumnya subjek memiliki densitas asupan protein dan energi yang cukup namun densitas asupan kalsium, vitamin A, dan vitamin $C$ rendah. Densitas asupan energi, vitamin A, vitamin $\mathrm{C}$, kalsium, dan zat besi tidak berhubungan dengan IMT/U ( $>>0,05)$. Densitas energi memiliki hubungan negatif dengan harga pangan $(\mathrm{r}=-0,0622)$. Akan tetapi, densitas zat gizi berhubungan positif dengan harga pangan $(\mathrm{r}=0,614)$.
\end{abstract}

Kata kunci: densitas energi, harga pangan, indeks massa tubuh menurut umur, kualitas diet

\section{PENDAHULUAN}

Anak usia sekolah membutuhkan makanan dengan jumlah dan kualitas lebih tinggi dibandingkan orang dewasa. Asupan zat gizi yang cukup diperlukan karena anak usia sekolah sedang dalam masa pertumbuhan dan perkembangan. Data Riset Kesehatan Dasar (2013) menunjukkan bahwa prevalensi penduduk usia $\geq 10$ tahun mengonsumsi makanan berisiko masih cukup tinggi yaitu makanan dan minuman berpemanis $(53,1 \%)$ dan makanan berlemak $(40,7 \%)$. Berdasarkan data tersebut dapat dikatakan bahwa terdapat kecenderungan anak di Indonesia masih sering mengonsumsi makanan dengan nilai densitas energi tinggi. Konsumsi energi, gula, dan lemak jenuh yang berlebih namun rendah konsumsi buah, dan sayur dapat menunjukkan kualitas konsumsi yang rendah. Kualitas konsumsi yang baik dikaitkan dengan tingginya konsumsi buah dan sayur yang memiliki densitas energi rendah serta mencukupi kebutuhan makronutrien secara tepat (Patterson 2010). Rasa yang manis dan gurih menjadikan makanan dan minuman manis dan tinggi lemak lebih banyak disukai oleh masyarakat dibandingkan dengan makanan kaya zat gizi seperti sayur dan buah sehingga konsumsi dari makanan tersebut menyebabkan gizi lebih.

\footnotetext{
"Korespondensi: Telp: +6281298027977, Surel: yuriekaningrum@gmail.com
} 
Prevalensi gizi lebih meningkat dari tahun ke tahun, baik di negara maju maupun negara yang sedang berkembang. Pada tahun 2010, 35 juta anak di negara berkembang menderita gizi lebih. Prevalensi gizi lebih pada anak di dunia meningkat dari 4,2\% pada tahun 1990 menjadi $6,7 \%$ pada tahun 2010 (Onis et al. 2010). Gizi lebih pada masa anak berisiko tinggi menjadi obesitas di masa dewasa dan berpotensi mengalami penyakit metabolik dan penyakit degeneratif di masa mendatang. Data Riskesdas (2013) menunjukkan bahwa prevalensi gizi lebih pada anak 5-12 tahun di Provinsi DKI Jakarta sebesar $30,1 \%$, prevalensi gemuk sebesar $16,1 \%$, sedangkan prevalensi obesitas adalah sebesar 14,0\%. Angka tersebut lebih besar dibandingkan dengan angka rata-rata nasional. Semua wilayah di DKI Jakarta prevalensinya di atas $10,0 \%$. Masalah kegemukan juga sudah mulai tampak pada kelompok kuintil teratas.

Terdapat beberapa argumen mengenai biaya makan yang juga memengaruhi kualitas konsumsi dan juga berkontribusi terhadap kesenjangan sosial di bidang kesehatan (Drewonski 2015). Hasil penelitian terdahulu menunjukkan bahwa makanan padat energi yang mengandung lemak, minyak, dan gula tambah-an menyediakan banyak kalori namun dengan biaya yang murah, sedangkan makanan yang rendah densitas energi seperti sayur dan buah mahal biayanya. Hal tersebut sejalan dengan penelitian lain di Amerika, Australia, dan di Belanda (Drewnowski 2010). Berbagai studi terkait gradien sosial dalam jumlah gizi lebih juga mene-mukan bahwa hubungan kemiskinan dan gizi lebih dapat dipengaruhi oleh biaya yang rendah terhadap makanan yang padat energi dan diperkuat oleh palatabilitas dari gula dan lemak. Hal tersebut menunjukkan bahwa rasa yang lezat dari makanan manis dan berlemak mudah dikonsumsi secara berlebihan sehingga menjadi prekursor langsung dalam penambahan berat badan (Drewonski 2015).

Tahun 2010, Drewnowski mengembangkan konsep densitas zat gizi pangan dengan tujuan untuk mengidentifikasi jenis pangan yang mengandung cukup zat gizi dengan biaya yang relatif terjangkau, sehingga dapat meminimalisir pengeluaran makanan dengan tetap memperoleh asupan zat gizi yang cukup dari makanan tersebut. Di samping itu, konsep densitas gizi juga dapat diaplikasikan dalam kehidupan sehari-hari untuk membantu seseorang dalam memilih pangan dengan jumlah yang tepat sesuai dengan prinsip gizi seimbang. Densitas asupan zat gizi juga dapat menggambarkan kecukupan zat gizi individu ataupun rumah tangga yang selanjutnya dapat memengaruhi status gizi individu atau rumah tangga tersebut. Tujuan dari penelitian ini adalah untuk 1) mengidentifikasi densitas energi makanan, densitas zat gizi pangan, densitas asupan zat gizi, harga pangan, dan status gizi anak; 2) menganalisis hubungan antara densitas energi makanan dengan densitas zat gizi pangan; 3) menganalisis hubungan antara densitas energi makanan dengan harga pangan; 4) menganalisis hubungan antara densitas zat gizi pangan dengan harga pangan; serta 5) menganalisis hubungan densitas asupan zat gizi dengan status gizi.

\section{METODE}

\section{Desain, tempat, dan waktu}

Desain penelitian ini adalah cross sectional. Penelitian dilakukan di Sekolah Dasar Negeri (SDN) Pekayon 16 Pagi, Kelurahan Pekayon, Kecamatan Pasar Rebo, Jakarta Timur. SDN Pekayon 16 Pagi dijadikan lokasi penelitian dan dipilih secara purposive dengan pertimbangan sekolah tersebut memiliki keluarga dengan status sosial ekonomi yang heterogen dan memiliki jumlah murid yang paling banyak dibandingkan dengan SD lain di Kelurahan Pekayon. Penelitian dilakukan pada bulan Desember 2015 sampai dengan Mei 2016.

\section{Jumlah dan cara pengumpulan data}

Populasi dalam penelitian ini adalah siswa kelas 3,4 dan 5 SD Pekayon 16 Pagi. Kriteria inklusi adalah siswa/i yang kondisinya sehat, bersedia mengikuti penelitian dan tidak sedang menjalani upaya pola makan seperti diet. Jumlah subjek diturunkan berdasarkan formula sebagai berikut:

$$
\begin{gathered}
n=\frac{n_{0}}{1+\frac{n_{0}}{N}} \\
n_{0}=\frac{s^{2} t \alpha / 2}{{ }^{2}(v)}
\end{gathered}
$$

Keterangan :

$=$ nilai $\mathrm{t}$ pada derajat kepercayaan $95 \%$

$\mathrm{n} \quad=$ jumlah subjek kasar (adjusted)

$t \alpha / 2=$ jumlah subjek

$\mathrm{N}=$ jumlah populasi

$\mathrm{s} \quad=$ standar deviasi

$\mathrm{d}=$ presisi atau ketepatan yang diinginkan $(5 \%)$.

Penelitian oleh Simanjuntak dan Hartono (2010) menemukan bahwa rata-rata z-skor IMT/U anak usia 10 sampai dengan 12 tahun di SD 04 Petang adalah sebesar 1,6 dengan standar deviasi 0,4. Berdasarkan rumus di atas diperlu- 
kan jumlah subjek sebanyak 156 . Untuk mengantisipasi drop out, maka peneliti menambahkan jumlah subjek sebanyak 10\% dari jumlah subjek minimum, sehingga didapatkan total subjek sebesar 172 siswa. Akan tetapi, subjek yang dimasukkan dalam penelitian ini berjumlah 158 karena data yang tidak lengkap dan tidak bersedia mengikuti penelitian. Walaupun subjek diturunkan berdasarkan formula penarikan subjek secara acak sederhana, namun penarikan subjek dilakukan melalui penarikan acak berlapis dengan alokasi proporsional.

Nama, umur, dan tanggal lahir anak diperoleh dengan pengisian kuesioner oleh anak. Data konsumsi pangan anak diketahui dengan metode food recall 2 x 24 jam pada hari sekolah dan hari libur. Berat badan anak diukur langsung menggunakan timbangan injak yang telah dikalibrasi dengan ketelitian $0,1 \mathrm{~kg}$, dan pengukuran tinggi badan anak menggunakan microtoise dengan ketelitian $0,1 \mathrm{~cm}$. Data status gizi anak diperoleh dengan menggunakan indeks massa tubuh berdasarkan umur (IMT/U) dengan menggunakan WHO Anthroplus 2007. Harga pangan diperoleh dengan metode mystery guest ke pasar, toko, atau tempat penjualan makanan lainnya yang menjual makanan yang dikonsumsi oleh anak. Penelitian ini telah mendapatkan persetujuan Etik dari Komite Etik Penelitian Kesehatan Fakultas Kedokteran Universitas Indonesia No.274/UN2.F1/ ETIK/2016.

\section{Pengolahan dan analisis data}

Data diolah serta dianalisis secara deskriptif dan inferensia dengan menggunakan program Microsoft Excel 2007 dan program SPSS 16.0 for Windows. Data konsumsi secara kuantitatif dihitung menggunakan jumlah dan jenis pangan aktual yang dikonsumsi berdasarkan food recall 2 x 24 pada hari sekolah dan hari libur. Data konsumsi pangan kemudian dikonversikan ke dalam bentuk energi, protein, lemak, karbohidrat, dan zat gizi lainnya menggunakan Daftar Komposisi Bahan Makanan (2007). Magnesium, kalium, natrium, dan asam lemak jenuh dihitung menggunakan software Nutrisurvey dan gula tambahan diperoleh dari nutrition fact produk makanan. Data asupan per hari menurut jenis pangan dikonversi ke dalam gram dan kilokalori (kkal). Nilai atau skor densitas energi pangan dihitung menggunakan metode dietary energy density (DED) dengan membandingkan jumlah asupan energi (kkal) dengan total berat pangan (gram).

Metode yang digunakan untuk menentukan densitas zat gizi pangan adalah Nutrient Rich Food Index (NRF 9.3), yang merekomendasikan untuk mengoptimalkan 9 jenis zat gizi esensial yaitu protein, serat, vitamin $\mathrm{A}$, vitamin $\mathrm{C}$, vitamin $\mathrm{E}$, kalsium $(\mathrm{Ca})$, zat besi $(\mathrm{Fe})$, magnesium $(\mathrm{Mg})$, dan kalium (K) dan membatasi konsumsi tiga jenis zat gizi yaitu gula tambahan, asam lemak jenuh, dan natrium (Drewnowski \& Fulgoni 2009). Persamaan yang digunakan untuk menghitung densitas zat gizi pangan dengan metode NRF 9.3 adalah sebagai berikut:

NRF $9.3=\sum 9(\% \mathrm{DV} / 100 \mathrm{kkal})-\sum 3(\% \mathrm{MRV} / 100 \mathrm{kkal})$

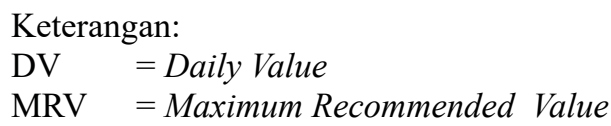

Densitas asupan zat gizi (DG) dihitung berdasarkan Drewnowski (2005) dan diklasifikasikan berdasarkan standar dari FAO. Rumus perhitungan densitas asupan zat gizi adalah rasio antara asupan zat gizi dan asupan energi kemudian dikalikan dengan $1.000 \mathrm{kkal}$.

Data mengenai harga pangan diperoleh dengan melakukan survei ke pasar, toko, atau tempat penjualan makanan lainnya yang menjual makanan yang dikonsumsi oleh anak. Harga pangan dikonversikan ke dalam rupiah/100 kkal. Pengklasifikasian status gizi anak diperoleh berdasarkan indikator IMT/U yaitu overweight $(+1$ $\mathrm{SD}<\mathrm{Z}<+2 \mathrm{SD}$ ), obesitas ( $+2 \mathrm{SD}<\mathrm{Z}<+3 \mathrm{SD}$ ), normal ( $-2 \mathrm{SD}<\mathrm{Z}<+1 \mathrm{SD})$, thinness $(-3 \mathrm{SD}<\mathrm{Z}<-2$ $\mathrm{SD})$, dan overthinness (<-3 SD) (WHO).

Statistik deskriptif yang digunakan adalah distribusi frekuensi dan persentase yang disajikan dalam bentuk tabel. Regresi linier sederhana digunakan untuk menganalisis hubungan antara densitas energi makanan dengan densitas zat gizi pangan. Uji korelasi Pearson dilakukan untuk mengetahui hubungan antara status gizi anak dengan densitas energi konsumsi, densitas vitamin $\mathrm{C}$, densitas protein serta densitas kalsium. Selain itu, korelasi Pearson juga digunakan untuk menganalisis hubungan antara densitas energi makanan dan densitas gizi pangan dengan harga pangan. Sementara itu, uji korelasi Spearman digunakan untuk mengetahui hubungan antara status gizi anak dengan densitas zat besi, dan densitas vitamin A.

\section{HASIL DAN PEMBAHASAN}

\section{Usia dan jenis kelamin}

Penelitian ini menganalisis subjek usia sekolah dari rentang usia 8-13 tahun. Subjek lebih banyak ditemukan berusia antara 10-13 tahun, dengan jumlah sebanyak 101 orang $(63,9 \%)$. Berdasarkan jenis kelamin, subjek ditemukan paling banyak berjenis kelamin laki-laki sebesar 84 orang $(53,16 \%)$. 
Ekaningrum dkk.

\section{Status gizi anak}

Subjek kurus berjumlah 18 orang $(11,4 \%)$, subjek dengan status gizi normal berjumlah 95 orang $(60,1 \%)$ dan subjek gemuk sebanyak 45 orang $(28,5 \%)$. Dijelaskan lebih lanjut, subjek yang gemuk lebih banyak ditemukan pada lakilaki dibandingkan pada perempuan $(31,0 \%)$. Hal ini sejalan dengan pernyataan Proper et al. (2006) bahwa laki-laki cenderung lebih besar kemungkinannya untuk menjadi overweight atau obesitas daripada wanita karena laki-laki cenderung untuk menghabiskan lebih banyak waktu untuk santai saat akhir minggu atau waktu senggang.

\section{Densitas energi dan zat gizi pangan}

Densitas energi dan zat gizi pangan merupakan suatu instrumen yang dikembangkan dengan tujuan untuk mengetahui dan mengidentifikasi total energi serta komposisi zat gizi dari suatu pangan sehingga selanjutnya dapat digunakan sebagai pedoman dalam pemilihan pangan yang mengandung cukup energi dan zat gizi sesuai dengan kebutuhan masing-masing individu (Drewnowski 2010; Jayanti 2014). Keunggulan dari metode NRF 9.3 ini adalah perhitungan berdasarkan 9 zat gizi esensial dan 3 zat gizi yang dibatasi serta dapat menjelaskan persentase dengan variasi tertinggi dari skor Healthy Eating Index (HEI) 2005 yang telah divalidasi.

Sama halnya dengan yang dilakukan Drewnowski (2010), jenis pangan yang digunakan dalam instrumen ini adalah pangan yang memenuhi kriteria dimana pangan tersebut sering dikonsumsi oleh subjek dan memiliki kandungan zat gizi yang penting. Selanjutnya berdasarkan skor densitas energi dan zat gizi dari masingmasing pangan, nilai median skor densitas energi dan zat gizi per jenis kelompok pangan dapat ditentukan. Nilai median dari skor densitas energi dan zat gizi per jenis kelompok pangan tersebut dapat mendeskripsikan kualitas pangan yang umum dikonsumsi masyarakat (Drewnowski 2010).
Ukuran lingkaran menunjukkan banyaknya jenis pangan berdasarkan kelompok pangan (Gambar 1). Berdasarkan pendekatan menggunakan indeks NRF 9.3, skor densitas zat gizi pangan yang dikonsumsi subjek sebagian besar termasuk kategori kuintil 1 dan 2, artinya kualitas pangan subjek masih dalam kategori kurang baik. Penelitian Drewnowski (2010) menunjukkan bahwa apabila skor densitas zat gizi pangan semakin tinggi dan skor densitas energi pangan semakin rendah maka kualitas pangan tersebut semakin baik pula.

Drewnowski dan Fulgoni (2009) mengemukakan bahwa berbagai model NRF mendapatkan hasil yang sama dengan penelitian terdahulu dan menyimpulkan bahwa semakin banyak zat gizi esensial yang dimasukkan ke dalam model, maka hubungannya dengan densitas energi semakin lemah. Dari skor densitas zat gizi pangan dan DED berbagai makanan yang dikonsumsi, dilakukan regresi linier sederhana untuk melihat hubungan antara keduanya. Persamaan yang didapatkan adalah $\mathrm{y}=13,23-3,01$ DED, dengan keterangan bahwa y adalah nilai NRF 9.3/100 kkal. Makna persamaan tersebut adalah jika nilai densitas energi makanan meningkat sebesar 1 unit satuan maka skor densitas zat gizi pangan mengalami penurunan sebesar 3,01.

\section{Harga pangan}

Nilai gizi pangan sangat bervariasi dalam satu kelompok pangan. Oleh karena itu, analisis dalam penelitian ini berdasarkan sub kelompok pangan. Center of Policy Nutrition and Promotion-USDA (CNPP USDA) mengonversikan harga pangan menjadi dolar per serving dan 100 kkal. Standar yang digunakan dalam penelitian ini adalah rupiah per kkal. Skor NRF/10.000 rupiah dihitung untuk mengetahui nilai NRF yang terkandung dalam pembelian pangan seharga 10.000 rupiah.

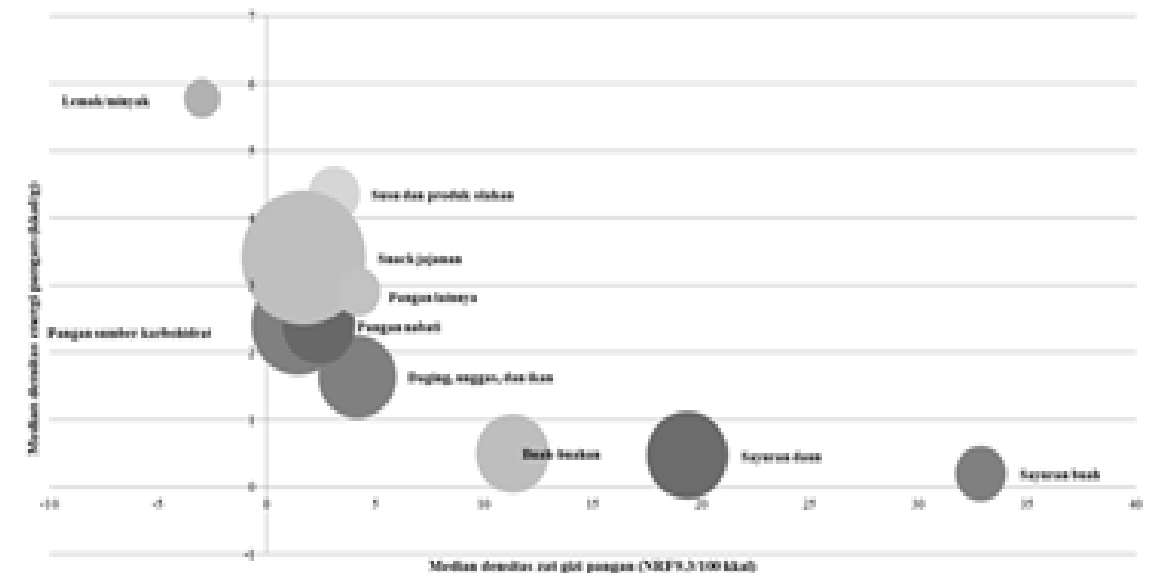

Gambar 1. Sebaran kualitas zat gizi pangan berdasarkan median skor densitas energi dan zat gizi pangan 
Pembagian antara skor indeks NRF dengan harga per serving merupakan sebuah pendekatan untuk mengidentifikasi pangan yang kaya akan zat gizi dan harganya terjangkau. Penelitian yang dilakukan oleh Drewnowski (2010) di Amerika Serikat yang menunjukkan bahwa jus jeruk, susu, sereal yang siap saji, kentang, sayur, buah dan telur memiliki nilai NRF per dolar tertinggi. Maillot et al. (2007) mengemukakan bahwa kelompok pangan sayur dan buah memiliki kualitas gizi yang paling tinggi namun berkaitan dengan tingginya biaya pangan tersebut. Median skor indeks NRF dan median harga pangan dalam sub kelompok pangan yang telah dirangkum dalam Tabel 1.

\section{Hubungan densitas asupan zat gizi dan status gizi}

Densitas energi yang dikonsumsi dihitung menggunakan total energi makanan dan minuman sehari yang dikonsumsi dibagi dengan berat pangan sehari (Annisa \& Tanziha 2014). Pada penelitian ini, standar total energi yang digunakan adalah per $1.000 \mathrm{kkal}$.

Densitas asupan energi tidak berhubungan secara signifikan dengan status gizi namun memiliki korelasi positif yang cukup kuat antara keduanya $(\mathrm{r}=0,402)($ Tabel 2$)$. Hal ini menandakan bahwa semakin tinggi densitas energi konsumsi maka semakin tinggi pula z-skor IMT/U. Penelitian yang dilakukan oleh Rolls (2006) menunjukkan hasil yang sejalan dengan penelitian ini dimana terdapat hubungan yang positif antara densitas energi konsumsi yang tinggi de- ngan berat badan pada anak-anak yang berumur 2 sampai dengan 8 tahun.

Sebagian besar subjek memiliki densitas protein yang cukup. Hasil yang diperoleh menunjukkan korelasi positif namun lemah $(\mathrm{r}=0,086)$ dan tidak signifikan. Sama halnya dengan densitas asupan zat gizi lain, densitas kalsium tidak berhubungan secara signifikan dengan status gizi dan terdapat hubungan yang sangat lemah. Sebagian besar subjek masih memiliki densitas asupan kalsium yang rendah. Namun, penelitian Amare et al. (2012) menunjukkan bahwa anak usia sekolah di Ethiopia baik normal maupun stunting tidak ada yang mengalami defisiensi kalsium. Densitas zat besi memiliki nilai korelasi positif yang tertinggi $(\mathrm{r}=0,146)$ terhadap status gizi namun menunjukkan tidak ada hubungan yang signifikan antara densitas zat besi dengan status gizi. Zat besi memiliki peranan penting dalam pertumbuhan linear. Amare et al. (2012) menunjukkan bahwa terdapat hubungan positif antara z-skor tinggi badan berdasarkan umur $(\mathrm{TB} / \mathrm{U})$ dengan level zat besi serum, walaupun tidak signifikan $(\mathrm{r}=0,139, \mathrm{p}>0,05)$.

Sebagian besar subjek yang kurus dan normal ditemukan mengonsumsi makanan yang masih rendah densitas vitamin A dan vitamin C. Densitas vitamin A dalam penelitian ini menunjukkan hubungan yang tidak signifikan namun memiliki korelasi positif dengan status gizi $(\mathrm{r}=0,083)$. Vitamin A memengaruhi fungsi imunitas sehingga defisiensi vitamin A dapat meningkatkan risiko stunting (Eckhardt et al. 2005). Hadi et al. (2000) menunjukkan bahwa suple-

Tabel 1. Sebaran kelompok pangan berdasarkan skor NRF dan harga pangan

\begin{tabular}{|c|c|c|c|}
\hline Sub kelompok pangan & NRF 9.3/100 kkal & $\begin{array}{c}\text { Harga (Rp)/100 } \\
\text { kkal }\end{array}$ & $\begin{array}{l}\text { Skor NRF 9.3/ } \\
10.000 \text { rupiah* }\end{array}$ \\
\hline Pangan sumber karbohidrat $(n=7)$ & 2,68 & 727,10 & 67,26 \\
\hline Mie instan $(n=1)$ & 0,7 & 750,00 & 9,37 \\
\hline Roti $(n=1)$ & 0,42 & $1.725,22$ & 2,46 \\
\hline Daging dan unggas $(n=3)$ & 0,49 & $4.493,26$ & 1,38 \\
\hline Ikan asin/air laut $(\mathrm{n}=2)$ & 7,26 & $7.997,45$ & 10,72 \\
\hline Ikan air tawar $(\mathrm{n}=4)$ & 5,32 & $12.221,24$ & 14,03 \\
\hline Telur ayam $(\mathrm{n}=1)$ & 2,88 & $1.394,58$ & 20,66 \\
\hline Susu $(n=3)$ & 2,93 & $2.197,06$ & 12,82 \\
\hline Pangan nabati $(\mathrm{n}=5)$ & 3,17 & $1.514,76$ & 54,22 \\
\hline Pangan sayuran daun $(n=9)$ & 34,15 & $11.999,67$ & 84,90 \\
\hline Buah-buahan $(n=6)$ & 15,59 & $5.830,64$ & 25,90 \\
\hline Chiki (n=2) & 1,33 & $1.771,13$ & 7,63 \\
\hline Biskuit $(n=6)$ & 0,66 & $1.405,67$ & 5,87 \\
\hline Kerupuk $(n=2)$ & 1,49 & $2.811,65$ & 19.35 \\
\hline Minuman manis dan eskrim $(n=5)$ & 2,60 & $4.521,18$ & 3,75 \\
\hline Pangan lainnya $(n=4)$ & 4,21 & $1.968,55$ & 17,23 \\
\hline Lemak/minyak $(n=3)$ & $-2,98$ & $1.419,91$ & - \\
\hline
\end{tabular}


Ekaningrum dkk.

Tabel 2. Hubungan densitas asupan zat gizi dengan status gizi

\begin{tabular}{|c|c|c|c|c|c|}
\hline Densitas asupan zat gizi & $\begin{array}{l}\text { Kurus } \\
\mathrm{n}(\%) \\
\end{array}$ & $\begin{array}{c}\text { Normal } \\
\mathrm{n}(\%) \\
\end{array}$ & $\begin{array}{c}\text { Gemuk } \\
\mathrm{n}(\%) \\
\end{array}$ & $\mathrm{r}$ & $\mathrm{p}$ \\
\hline $\begin{array}{l}\text { Densitas energi* } \\
\text { Rendah }(<1,6 \mathrm{kkal} / \mathrm{g}) \\
\text { Sedang }(1,6-2,0 \mathrm{kkal} / \mathrm{g}) \\
\text { Tinggi }(>2,0 \mathrm{kkal} / \mathrm{g})\end{array}$ & $\begin{array}{l}3(42,9) \\
15(28,3) \\
27(27,6)\end{array}$ & $\begin{array}{c}3(42,9) \\
30(56,6) \\
62(63,3)\end{array}$ & $\begin{array}{l}1(14,3) \\
8(15,1) \\
9(9,2)\end{array}$ & 0,402 & 0,607 \\
\hline $\begin{array}{l}\text { Densitas protein }(\mathrm{g})^{*} \\
\text { Rendah }(<20) \\
\text { Cukup }(20-40)\end{array}$ & $\begin{array}{l}4(17,4) \\
41(30,4)\end{array}$ & $\begin{array}{l}16(69,6) \\
79(58,5)\end{array}$ & $\begin{array}{c}3(13,0) \\
15(11,1)\end{array}$ & 0,086 & 0,283 \\
\hline $\begin{array}{l}\text { Densitas kalsium }(\mathrm{mg})^{*} \\
\text { Rendah }(<500) \\
\text { Cukup }(500-800)\end{array}$ & $\begin{array}{c}44(28,4) \\
1(33,3)\end{array}$ & $\begin{array}{l}93(60,0) \\
2(66,7)\end{array}$ & $\begin{array}{c}18(11,6) \\
0(0,0)\end{array}$ & 0,001 & 0,991 \\
\hline $\begin{array}{l}\text { Densitas zat besi }(\mathrm{mg})^{* *} \\
\text { Rendah }(<7) \\
\text { Cukup }(7-40)\end{array}$ & $\begin{array}{c}41(28,1) \\
4(33,3)\end{array}$ & $\begin{array}{c}90(61,6) \\
5(41.7)\end{array}$ & $\begin{array}{l}15(10,3) \\
3(25,0)\end{array}$ & 0,146 & 0,067 \\
\hline $\begin{array}{l}\text { Densitas vitamin A }(\mu \mathrm{g} \mathrm{RE})^{* *} \\
\text { Rendah }(<700) \\
\text { Cukup }(700-1000) \\
\text { Tinggi }(>1.000)\end{array}$ & $\begin{array}{l}39(26,4) \\
6(66,7) \\
1(20,0)\end{array}$ & $\begin{array}{l}89(61,8) \\
3(33,3) \\
3(60,0)\end{array}$ & $\begin{array}{c}17(11,8) \\
0(0,0) \\
1(20,0)\end{array}$ & 0,083 & 0,301 \\
\hline $\begin{array}{l}\text { Densitas vitamin C }(\mathrm{mg}) * \\
\text { Rendah }(<50)\end{array}$ & $45(28,5)$ & $95(60,1)$ & $18(11,4)$ & 0,007 & 0,932 \\
\hline
\end{tabular}

*uji korelasi Pearson, **uji korelasi Spearman.

mentasi vitamin A dapat meningkatkan pertumbuhan linear sekitar 0,10 sampai dengan $0,39 \mathrm{~cm}$ selama 4 bulan pada balita yang mengalami defisiensi vitamin A di Indonesia. Secara keseluruhan subjek mengonsumsi makanan yang rendah densitas vitamin C. Rendahnya asupan vitamin C dapat memengaruhi konsentrasi ascorbic acid di dalam tubuh. Wanita memiliki konsentrasi yang lebih tinggi dibandingkan dengan laki-laki (Gibson 2005).

\section{Hubungan densitas gizi dengan harga pangan}

Menurut Darmon et al. (2005), semakin tinggi densitas energi makanan maka semakin rendah biaya makanannya. Pada masyarakat kalangan menengah kebawah dan tidak bekerja, biaya dan rasa merupakan kunci determinan dari pemilihan makanan. Masalah harga pangan tetap menjadi hal yang menghambat perubahan pola makan pada keluarga dengan pendapatan menengah ke bawah. Hal tersebut dapat menjadi penjelasan mengapa pengonsumsian makanan yang sehat seperti buah dan sayur masih sangat rendah. Hasil penelitian lain juga menunjukkan bahwa kemiskinan dan obesitas berhubungan berkaitan dengan biaya yang rendah dan palatabilitas yang tinggi pada makanan padat energi (Molarius et al. 2000).

Korelasi antara densitas energi makanan dengan harga pangan menunjukkan hasil yang negatif namun dalam kategori cukup kuat. Korelasi antara densitas zat gizi pangan dengan harga pangan diperoleh bernilai positif dengan kategori cukup kuat $(r=0,614)$ (Tabel 3). Hal tersebut menunjukkan bahwa semakin tinggi densitas zat gizi pangan maka semakin mahal harga pangan.

Hasil penelitian ini sejalan dengan penelitian yang dilakukan oleh Darmon et al. (2005) yang mengungkapkan bahwa cukup banyak studi yang melibatkan database makanan di Perancis yang menunjukkan bahwa semakin tinggi skor densitas zat gizi pangan maka akan semakin tinggi biaya per kalori yang dibutuhkan. Umumnya, pangan yang kaya akan zat gizi lebih mahal per kkal dibandingkan dengan pangan yang rendah nilai zat gizinya.

Tabel 3. Hubungan densitas gizi dengan harga pangan

\begin{tabular}{lcc}
\hline \multicolumn{1}{c}{ Variabel } & $\mathrm{r}$ & $\mathrm{p}$ \\
\hline $\begin{array}{l}\text { Densitas energi makanan } \\
(\mathrm{kkal} / \mathrm{g})^{*}\end{array}$ & $-0,622$ & 0,0001 \\
$\begin{array}{l}\text { Densitas zat gizi pangan } \\
(\mathrm{NRF} 9.3 / 100 \mathrm{kkal}) *\end{array}$ & 0,614 & 0,0001 \\
\hline
\end{tabular}

Keterangan: *uji korelasi Spearman.

Skor NRF tertinggi per dolar juga didapatkan pada kentang, jus tomat, sup tomat, wortel, dan brokoli. Sayuran, sup dan jus yang sudah diolah menyediakan zat gizi yang terjangkau dan sering menjadi pilihan makanan bagi masyarakat dengan golongan menengah ke bawah. Penelitian yang dilakukan oleh Drewnowski (2010) di Amerika Serikat menunjukkan bahwa telur, kacang-kacangan, daging dan produk susu olahan merupakan sumber protein dengan biaya yang sangat rendah. Sedangkan buah dan sayur meru- 
pakan sumber vitamin $\mathrm{C}$ yang biayanya sangat rendah. Apabila dibandingkan antar kedua sumber zat gizi pangan tersebut maka susu, kentang, jus jeruk, sereal, dan buncis lebih murah rasio antara zat gizi dan harganya dibandingkan dengan sayuran dan buah. Sementara itu terbukti bahwa gandum yang padat energi, makanan manis, dan lemak merupakan pangan yang mengandung paling banyak kalori namun rendah nilai zat gizinya per satu dolar.

Hubungan antara kualitas pangan dengan harga pangan berbeda antar negara, kelompok umur, maupun indikator yang berbeda dalam kualitas pangan. Secara kontras, penelitian di Jepang menunjukkan hasil yang berbeda. Penelitian di negara tersebut menunjukkan bahwa semakin tinggi biaya bahan makanan, maka semakin tinggi densitas energi pangan, serta konsumsi kolesterol dan lemak jenuh total. Penelitian di Jepang menunjukkan perbedaan karena jenis makanan yang dikonsumsi di Jepang berbeda dengan makanan yang dikonsumsi di negara lainnya (Murakami et al. 2007). Beberapa penelitian mengemukakan bahwa makanan yang rendah densitas energinya seperti buah dan sayur memiliki energy cost yang tinggi dibandingkan dengan makanan yang memiliki densitas energi yang tinggi. Oleh karena itu, makanan yang memiliki densitas energi rendah lebih terjangkau bagi masyarakat dengan status sosial ekonomi ke bawah (Drewnowski \& Specter 2004).

\section{KESIMPULAN}

Hasil penelitian menunjukkan terdapat hubungan yang negatif antara densitas energi dengan harga pangan. Akan tetapi, terdapat hubungan yang positif antara densitas zat gizi pangan dengan harga pangan. Sebagian besar siswa/i SDN Pekayon 16 Pagi memiliki densitas asupan energi dan protein yang cukup namun rendah densitas asupan kalsium, vitamin A, dan vitamin C. Hal tersebut menunjukkan kualitas konsumsi pangan yang masih rendah.

Saran untuk orang tua adalah agar selektif dalam memilih makanan yang baik untuk anaknya dan mulai membiasakan diri mengganti makanan yang berlemak atau mengandung sodium tinggi dengan makanan yang dapat mencukupi kebutuhan makronutrien secara tepat dan terdapat cukup vitamin dan mineral. Sekolah dapat menggunakan hasil penelitian ini untuk memilih pangan yang memiliki densitas gizi yang tinggi dan harganya terjangkau. Selain itu, sekolah juga berperan penting dalam memberikan materi dan praktik gizi seimbang dalam pengajaran sehingga dapat membina perilaku gizi anak menjadi lebih baik. Petugas kesehatan juga dapat memberikan penyuluhan kepada anak terkait pengetahuan tentang pentingnya konsumsi sayur dan buah untuk menetralisir konsumsi energi dan makanan berlemak berlebih yang selama ini dikonsumsi oleh subjek. Penelitian untuk analisis lebih lanjut menggunakan berbagai model nutrient profiling system lainnya diperlukan dengan melibatkan data konsumsi pangan masyarakat Indonesia supaya dapat mengidentifikasi pangan yang biayanya terjangkau namun mengandung zat gizi yang cukup untuk meningkatkan kualitas kesehatan.

\section{DAFTAR PUSTAKA}

Amare B, Moges B, Fantahun B, Tafess K, Woldeyohannes D, Yismaw G, Ayane T, Yabutani T, Mulu A, Ota O. 2012. Micronutrient levels and nutritional status of school children living in Northwest Ethiopia. Nutrition Journal 11(1):108.

Annisa PA, Tanziha I. 2014. Densitas energi konsumsi, status gizi, dan daya ingat sesaat anak usia sekolah dasar. J Gizi Pangan 9(3):187-194.

Darmon N, Darmon M, Maillot M. 2005. A nutrient density standard for vegetables and fruits: nutrients per calorie and nutrients per unit cost. J Am Diet Assoc 105(12):18811887.

[Depkes RI] Departemen Kesehatan Republik Indonesia. 2013. Laporan Nasional Riskesdas 2013. Jakarta: Riskesdas.

Drewnowski. 2015. Contribution of food prices and diet cost to socioeconomic disparities in diet quality and health: a systematic review and analysis. Nutrition Reviews 73(10):643-660.

Drewnowski A. 2010. The Nutrient Rich Foods Index helps to identify healthy, adorable foods. Am J Clin Nutr 91(4):1095S-1101S.

Drewnowski A, Keast DR, Fulgoni VL. 2009. Developmental and Validation of The $\mathrm{Nu}-$ trient Rich Food Index: A Tool to Measure Nutritional Quality Foods. J Nutr 139(8): 1549-1554.

Drewnowski A, Specter SE. 2004. Poverty and obesity: the role of energy density and energy costs. Am J Clin Nutr. 79(1):6-16.

Eckhardt CL, Suchindran C, Gordon-Larsen P, Adair LS. 2005. The association between diet and height in the postinfancy period changes with age and socioeconomic status in Filipino youths. J Nutr 135(9):21922198.

Gibson. 2005. Principle of Nutritional Assessment. New York: Oxford University Press.

Hadi H, Stoltzfus RJ, Dibley MJ, Moulton LH, West KP, Kjolhede CL, Sadjimin T. 2000. Vitamin A supplementation selectively 
Ekaningrum dkk.

improves the linear growth of Indonesian preschool children: results from a randomized controlled trial. Am J Clin Nutr 71(2): 507-513.

Jayanti LD. 2014. Studi aspek sosial ekonomi dan budaya, konsumsi pangan, serta densitas gizi pada masyarakat Kasepuhan Ciptagelar Jawa Barat. [Tesis]. Bogor: Institut Pertanian Bogor.

Maillot, Darmon N, Darmon M, Lafay L, Drewnowski. 2007. Nutrient-dense food groups have high energy costs: An econometric approach to nutrient profilling. J Nutr 137(7):1815-1820.

Molarius A, Seidell JC, Sans S, Tuomilehto J, Kuulasma K. 2000. Educational level, relative body weight, and changes in their association over 10 years: an international perspective from the WHO Monica Project. AJPH 90(8):1260-1268.

Murakami K, Sasaki S, Okubo H. 2007. Monetary costs of dietary energy reported by young Japanese women: association with food and nutrient intakeand body mass index.
Public Health Nutr 10(12): 1430-1439.

Onis M, Blossner M, Borghi E. 2010. Global prevalence and trends of overweight and obesity among preschool children. Am J Clin Nutr 92(5):1257-1264.

Patterson. 2010. Dietary energy density as a marker of dietary quality in Swedish children and adolescents : the European Youth Heart Study. Eur J Clin Nutr 64(4):1-8.

Proper KI, Cerin E, Brown WJ, Owen N. 2006. Sitting time and socio - economic differences in overweight and obesity. Int J Obes 31(1):169-176.

Rolls BJ, Ledikwe JH, Blanck MH, Khan LK, Serdula MK, Seymour JD, Tohill C.2006. Dietary energy density is associated with energy intake and weight status in US Adults. Am J Clin Nutr 83(6):1362-1368.

[USDA] United States Department of Agriculture. 2008. Development of The CNPP Prices Database.

[WHO] World Health Organization. 2000. Obesity: Preventing and Managing the Global Epidemic. Geneva: WHO Technical Report Series. 